of parts, both in man and animals, is but the visible effect of a corresponding variety and gradation of the nisus formativus, or the solur ganglion, the germ of all to be afterwards developed.

$$
\begin{aligned}
& \text { "First chain of being, which from God began, } \\
& \text { Nature's ethereal, human, angel, man, } \\
& \text { Beast, bird, fish, insect, what no eye can see, } \\
& \text { No glass can reach, from infuite to thee : } \\
& \text { From thee to nothing." } \\
& \text { PorE. }
\end{aligned}
$$

It may be added that the possession of the three nervons systems in man and in the higher order of animals does not pre-suppose that those which have only two or even one, have been insufficiently provided for. The organism of the polypus and oyster is as nicely adapted to their wants and the circumstances which surround them, as is the organism of man.

In many instances among the lower classes of animals it appears that Nature has intended so to economize her means that one part shall serve the purposes of two or even more, and in others she has so concentrated her forces that it is really astonishing. The reproduction of lost parts in the lobster and crab, and many other crustacea; and the extraordinary activity of certain of the external senses in some animals higher in the scale of organization than the crustacea, almost make one doubt on which side to consider the advantages! A division of labour is generally regarded as indispensable to perfectibility, but among the lowest classes of animals we find the opposite principle in operation:-thus the solar ganglion in certain animals executes the functions of both the spinal cord and the cerebrum; for in the absence of the brain and spinal cord, it is occasionally seen that both sensation and voluntary motion exist in the zoophytes. In the manner in which the infusoria and actiniæe pursue their prey, and in their selection of it; in the facility with which they recede from whatever may prove hurtful to them, and turn aside when they encounter one another, together with the highly sensitive and irritable nature of the organism of the medasurim generally; " we can hardly fail," as Dr. Roget truly observes, " to recognise the evidence of voluntary action." Herein we get at the nature of animal instinct, and which, in the absence of everything like a cerebrum and spinal cord, must be regarded as a specific function of the ganglionic system. Dr. Roget says, in his chapter on the "Comparative Physiology of the Nervous System, page 538, "But whatever may be their extent, it is probable that the sensorial operations of the zoophytes take place without the intervention of any common centre of action," meaning thereby that the sensorial operations, socalled, are performed independently of a brain. The same may be said of the mollusca and articulata. There are times, more over, when the vertebral animals, as fishes, reptiles, and birds, including the mammalia, and even man, perform actions of an instinctive and intellectual character, and that, too, without the intervention of any common centre of action. What is the course of that instinctive agency which determines the young among the several classes of animals above enumerated, including man, to seek each its particular means of support. In what originates the very keen choice which is displayed by all of them for that which nature has so especially predestined for their respective uses? What determines the peculiar habits and mode of life of any one of them? The immature condition of the brain in the infant being renders it perfectly impossible that it can exercise any, even the slightest, influence in the matter; and no one could venture to affirm that the spinal cord took any part in it. There can be no reason to doubt, but, on the other hand, every reason to feel assured, that to the same cause of the "sensorial operations" of the zoophytes, and of that peculiar instinct which enables the lower classes of animals generally to provide, not only for all the necessaries of life, but even to guard against contingencies and anticipate difficulties, whether they relate to the kind of habitation, the mode of progression, or to the kind of food required for their sustenance; in a word, to the same cause, the formative power or solar ganglion, which so beautifully adapts their individual habits, pursuits, and inclinations, to their peculiar organic conditions, and so providently harmonizes the natural laws, must also be referred whatever of instinct is, at any time, manifested in man, including the vertebrated animals.

The sudden and peculiar shrinking of the hydro when under the influence of fear, and the extreme caution and dexterity displayed by the infusory animalculæ in avoiding obstacles of any kind while swimming together in myriads in a single drop, are instinctive vital actions, arising from an inherent preservative principle derived from the solar ganglion, and similar in its nature to that which induces even us, in the moment of danger and doubt, to place our extended palm across the præcordia-thus the affected miss, though ignorant of physiology or pathology, and perhaps of all other ologies, if either alarmed, or professing to be so, at any sufficient or insufficient cause of personal danger, quickly applies her hand to the precordia; as if the solar plexus screamed "take care of me now:" What more reasonable than to expect that that organ, the sum of whose function may be in one word described as life, should preside over actions of the kind mentioned above, so indispensable as they are to both its integrity and well being!

The instinctive and mental (cerebral) faculties are occasionally seen acting in combination-e.g., the martins which, in a spirit of retaliation and vindictiveness, built up the hole which had access to the nest that certain sparrows had robbed them of, and so buried alive the predatory occupiers in a grave of their own seeking, afford an instance of a clear and distinct process of thought, of cerebration. The original construction of the nest was instinctive or ganglionic, but the subsequent act certainly cerebral; whilst both were perhaps of a decidedly "intellectual character." Dr. Darwin tells the following anecdote:- "A wasp on a gravel walk had caught a fly nearly as large as itself. Kneeling upon the ground I observed him separate the tail and head from the body part, to which the wings were attached. He then took the body part in his paws, and rose about two feet from the ground with it; but a gentle breeze wafting the wings of the fly, turned him round in the air, and he settled again with his prey on the gravel. I then distinctly observed him cut off with his mouth, first one of the wings, and then the other, after which he flew away with it unmolested by the wind." Now, I take it that the mere pursuit and selection of the fly by the wasp as its prey was an act purely instinctive, whilst the clipping off of the wings under the circumstance narrated shows it to have been cerebral.

The constructive habits of the bee, as shown in the mathematical accuracy with which each cell of the honeycomb is formed, are certainly ganglionic or instinctive in their nature and origin; if the same structure had even been conceived and executed by man, it would have been an act of the brain, and an equal perfection of it could only have resulted from habit and experience. Similar observations will apply to the beaver, and not less so to many birds, \&c. Such must be directly seen to be the legitimate and only conclusion, from the fact, that in some animals, without even a vestige of brain or spinal marrow, analogous phenomena are presented to our attention; the ganglionic system in them, as in the amyencephalous monster of Dr. M. Hall, is the only power of any kind they can command; they possess none other, and therefore must it be conceded, that the "sensorial operations," so called, are occasionally performed independently of a brain; and what is more, "the actions which are at one time instinctive, may at another spring from a different principle."*

\section{REPORT OF A CASE OF}

\section{AN EXTRAORDINARILY LARGE CALCULUS EXTRACTED PER URETHRAM WITH WEISS's \\ DILATOR AND FORCEPS.}

Bx HORACE HOWARD, Esq., M.R.C.S., New Buckenham.

The patient, Maria $\mathrm{N}-$ - , aged twenty-three years, had experienced for a long time much irritation about the kidneys and urinary apparatus, for which different palliative remedies were administered, but with little relief. The patient was lost sight of for some time, and I was again applied to; and upon introducing a sound, I found a stone, evidently of considerable magnitude. As soon as I could get the patient into a fit condition, I succeeded, with the aid of Weiss's dilator and forceps, after about two hours' gradual dilatation, in extracting, without cutting, a stone of oblong form, and rather rough, weighing two ounces, four drachms, and twelve grains; the longest circumference six inches and a quarter, shortest, five inches and a half; longest diameter, two inches and a quarter; shortest, one inch and $\frac{5}{12}$ ths. The patient rapidly recovered. Incontinence of urine continued for some time, but she can now retain about half a pint, and is in good health. A difficulty presented itself in the operation. The patient had had in early life, hip-joint disease, attended with absorption of the head of the fenur, consequently the thigh could not be flexed. New Buckenham, Norfolk, August, 1850.

* "lrstinct is an arbitrary connexion between certain internal feelings and * "Irstinct is an arbitrary connexion between certain internal feelings and
the will to execute particular movements, which, in this case, do not pro
ceed from imitation, babit, or the expectation of an advantage to be derived from them. The actions which are at one time instinctive, may, at rived from them. The actions which are at one tin
another, spring from a differeat principle." - MAYO. 